\section{Functional Oligosaccharide DFA III Forming Enzyme Produced by Microorganisms}

\section{Kazutomo Haraguchi ${ }^{*}$}

Food Research Institute, NARO, 2-1-12 Kannondai, Tsukuba-shi, Ibaraki 305-8642, Japan

*Corresponding author: Kazutomo Haraguchi, Food Research Institute, NARO, 2-1-12 Kannondai, Tsukuba-shi, Ibaraki 305-8642, Japan, Tel: +81-029-838-8073; Fax: +81-029-838-7996; E-mail: haraguti@affrc.go.jp

Received date: September 16, 2016; Accepted date: October 27, 2016; Published date: November 7, 2016

Copyright: (c) 2016 Haraguchi K. This is an open-access article distributed under the terms of the Creative Commons Attribution License, which permits unrestricted use, distribution, and reproduction in any medium, provided the original author and source are credited.

\begin{abstract}
Inulin is a polysaccharide found in various plants (chicory, dahlia, and so on). A unique oligosaccharide DFA III (di-fructose di-anhydride III) is formed from inulin with a special microbial enzyme. This enzyme was named as inulin fructotransferase (DFA III-producing) [EC 4.2.2.18]. The oligosaccharide DFA III has sweetness half as sucrose. The DFA III also has a special quality that promotes the assimilation of minerals ( $\mathrm{Ca}$, $\mathrm{Fe}$, and so on) from intestines. Therefore, the oligosaccharide DFA III has a unique potential for the prevention of osteoporosis and iron deficiency anaemia. The sales in the market of DFA III were started in 2004 in Japan. Now, we can purchase a product of supplement containing the DFA III and a mineral in a pharmacy and a convenience store in Japan. In this article, we summarize the research on the oligosaccharide DFA III forming enzyme produced by the microorganisms.
\end{abstract}

Keywords: Inulin; Oligosaccharide DFA III; Enzyme

\section{Introduction}

A huge amount of sugar (more than 500,000 tons) is produced from a sugar beet in Hokkaido area, Japan. Therefore, the production of beet sugar is a valuable industry of Hokkaido district, Japan. The consumption of sugar in Japan is gradually decreasing. Accordingly, to introduce an alternative crop for the sugar beet is desirable. In Europe (Germany, Belgium, and so on), a chicory was introduced as an alternative crop for the sugar beet. The root of chicory includes a polysaccharide inulin. The inulin is a storage polysaccharide found in plants (chicory, dahlia, and so on). The inulin is a fructose polymer $(\beta-2,1$ linked) terminated by a sucrose residue. In Europe, inulin produced from the chicory is used as a food material. For example, inulin is used as a component of a chocolate (as an alternative material of cocoa butter).

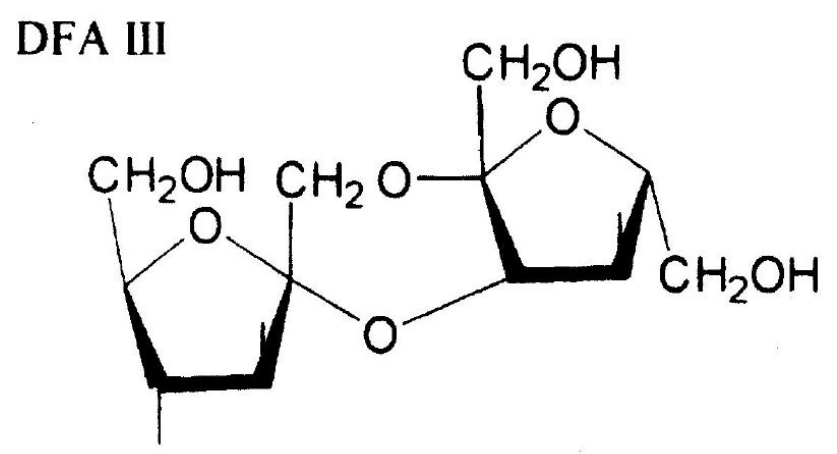

Figure 1: The chemical structure of oligosaccharide DFA III.

On the other hand, by the use of microbial enzymes, all sort of oligosaccharides are formed from inulin. The oligosaccharides have a potential for utilization, as a food, medicine, and so on. We have a unique oligosaccharide DFA III produced from inulin. In the DFA III, two molecules of fructose are bonded to each other at two portions. The DFA III has sweetness half as sucrose. The DFA III is a nonreducing sugar. The chemical structure of the oligosaccharide DFA III is presented in Figure 1. In this article, we summarize the research on the inulin fructotransferase (DFA III-producing) [EC 4.2.2.18] and the functional oligosaccharide DFA III.

\section{Discovery of Oligosaccharide DFA III Forming Enzyme}

On the research of inulin decomposing enzymes, inulinases [EC 3.2.1.7] produced by molds and yeasts were studied in the past. Subsequently, new inulin decomposing enzyme was reported by Uchiyama et al., for the first time [1]. This enzyme changed inulin into an oligosaccharide DFA III (di-fructose di-anhydride III) and a residual other oligosaccharides. This enzyme was named as inulin fructotransferase (DFA III-producing) [EC 4.2.2.18]. This new enzyme was produced by a microorganism, Arthrobacter ureafaciens. The microorganism Arthrobacter is a typical soil bacterium. This new enzyme was produced in a culture supernatant of the microorganism. The enzyme purification was performed with an ammonium sulfate precipitation, an acetone precipitation, and a gel filtration by Sephadex G-100 column. The purity of the enzyme protein was checked by a SDS-PAGE, and a pure enzyme (a single band) was obtained. The maximum activity of the enzyme was observed at pH 6.0 and 50. It was stable up to 50 . By a gel filtration, the molecular mass of the enzyme protein was presumed as $80 \mathrm{kDa}$.

\section{Short History on the Research of Inulin Fructotransferase (DFA III-Producing)}

Afterwards, there were several reports on the inulin fructotransferase (DFA III-producing) from Arthrobacter species. We purified the enzyme produced by Arthrobacter globiformis C11-1 [2]. The molecular mass of this enzyme was assumed to be $45 \mathrm{k}$ Da by SDS- 
Page 2 of 4

PAGE and $50 \mathrm{k}$ Da by gel filtration (HPLC). From these results, the enzyme was presumed to be a monomer. The enzyme showed maximum activity at $\mathrm{pH} 5.5$ and 55 , and the enzyme activity was stable up to 75 . Kawamura et al. investigated on the enzyme from Arthrobacter ilicis [3]. The molecular mass of this enzyme was presumed to be $27 \mathrm{kDa}$ by SDS-PAGE and $50 \mathrm{k}$ Da by gel filtration. Accordingly, the enzyme was assumed to be a dimer. The enzyme showed maximum activity at pH 5.5 and 60 . The enzyme was stable up to 70 . Yokota et al. purified the enzyme from Arthrobacter sp. H65-7 [4]. The molecular mass of the enzyme was assumed to be $49 \mathrm{kDa}$ by SDS-PAGE and $100 \mathrm{kDa}$ by gel filtration. From these data, the enzyme was presumed to be a dimer. This enzyme showed maximum activity at pH 5.5 and 60. The enzyme was stable up to 70 . We reported the enzyme produced by Arthrobacter sp. L68-1 [5]. The molecular mass of the enzyme was presumed $43 \mathrm{k}$ Da by SDS-PAGE and $73 \mathrm{k}$ Da by gel filtration. Therefore, the enzyme was assumed to be a dimer. The maximum activity of the enzyme was observed at pH 5.5-6.0 and 55. The enzyme was stable up to 80 for $60 \mathrm{~min}$. This heat-stability was highest among the enzymes reported up to now.
The oligosaccharide DFA III forming enzyme is also produced by other type of bacteria (not belongs to Arthrobacter). Kang et al. studied the enzyme produced by Bacillus sp. [6]. The molecular mass of the enzyme was assumed to be $62 \mathrm{k}$ Da by SDS-PAGE. This enzyme showed maximum activity at $\mathrm{pH} 6.0$ and 40 . The activity of the enzyme was stable up to 60 . We studied on the enzyme from Leifsonia sp. [7]. The molecular mass of this enzyme was assumed to be $44 \mathrm{k}$ Da by SDSPAGE, and $74 \mathrm{kDa}$ by gel filtration. Accordingly, this enzyme was presumed to be a dimeric enzyme. The enzyme showed maximum activity at $\mathrm{pH} 5.0$ and 65 . The enzyme was stable up to 80 . We investigated on the enzyme from Microbacterium sp. [8].

The molecular mass of the enzyme was presumed to be $45 \mathrm{kDa}$ by SDS-PAGE, and $46 \mathrm{kDa}$ by gel filtration. Therefore, the enzyme was assumed to be a monomeric enzyme. The enzyme showed maximum activity at pH 6.0 and 60 . The enzyme was stable up to 65 . Table 1 shows the summary of the properties of oligosaccharide DFA III forming enzyme produced by various microorganisms.

\begin{tabular}{|c|c|c|c|c|c|c|}
\hline \multirow{2}{*}{ Microorganism } & \multirow{2}{*}{ Optimum pH } & \multirow{2}{*}{${ }^{\circ} \mathrm{C}$} & \multirow{2}{*}{ Heat stability $\left({ }^{\circ} \mathrm{C}\right)$} & \multicolumn{2}{|c|}{ Molecular Mass (Kda) } & \multirow[t]{2}{*}{ References } \\
\hline & & & & SDS-PAGE & Gel-Filtration & \\
\hline Arthrobacter ureafaciens & 6 & 50 & 50 & & 80 & [1] \\
\hline Arthrobacter globiformis C11-1 & 5 & 55 & 75 & 45 & 50 & [2] \\
\hline Arthrobacter ilicis OKU17B & 5.5 & 60 & 70 & 27 & 50 & [3] \\
\hline Arthrobacter sp. H65-7 & 5.5 & 60 & 70 & 49 & 100 & [4] \\
\hline Arthrobacter sp. L68-1 & $5.5-6.0$ & 55 & 80 & 43 & 73 & [5] \\
\hline Bacillus sp. snu-7 & 6 & 40 & 60 & 62 & & [6] \\
\hline Leifsonia sp. T88-4 & 5 & 65 & 60 & 44 & 74 & [7] \\
\hline Microbacterium sp. S48-1 & 6 & 60 & 65 & 45 & 46 & [8] \\
\hline
\end{tabular}

Table 1: Comparison of the inulin fructotransferase (DFA III-producing ) from various microorganism.

\section{Cloning of Gene of Inulin Fructotransferase (DFA III- Producing)}

Sakurai et al. cloned the enzyme gene of Arthrobacter sp. H65-7 [9]. The gene had an open reading frame consisted with $1314 \mathrm{bp}$. The gene contained a structure of signal peptide ( 32 amino acids). It was assumed that the mature enzyme was composed of 405 amino acids. The molecular mass of the enzyme was calculated to be $43.4 \mathrm{kDa}$. The presumed amino acid sequence had a homology (49.8\%) with that of inulin fructotransferase (DFA I-producing) [EC 4.2.2.17] from Arthrobacter globiformis S14-3 [10]. The E. coli cells carrying the inulin fructotransferase (DFA III-producing) gene of Arthrobacter sp. H65-7 produced the active enzyme. Most of the expressed active enzyme existed within the $E$. coli cells.

We cloned the gene of the inulin fructotransferase (DFA IIIproducing) produced by Arthrobacter globiformis C11-1 [11]. The gene encoded an open reading frame consisting $1353 \mathrm{bp}$. In this gene, the initiation codon was presumed to be an unusual GTG (usually ATG). The gene had a structure of signal peptide ( 40 amino acids). The molecular mass of the enzyme was estimated as $43.4 \mathrm{kDa}$ from the sequence data. The assumed amino acid sequence of the enzyme had a homology (74.0 \%) with that of the Arthrobacter sp. H65-7. The deduced amino acid sequence had a homology $(45.1 \%)$ with that of inulin fructotransferase (DFA I-producing) from Arthrobacter globiformis S14-3 [10]. Figure 2 shows the homology of these presumed amino acid sequences. The cloned gene from $A$. globiformis C11-1 was expressed in the host vector system of E. coli (pUC 119, E. coli JM109). In this case, the active enzyme was expressed in both in a cell free extract and the culture supernatant. The ratio of the total activity expressed (cell free extract: culture supernatant) was 61: 39 .

\section{Production of DFA III Using an Immobilized Enzyme or a Membrane Reactor}

Jahnz et al. reported on an immobilization of inulin fructotransferase (DFA III-producing) [12]. They used calcium alginate as a carrier of immobilization. The prepared immobilized enzyme had an activity of $196 \mathrm{U}$ per gram gel. 


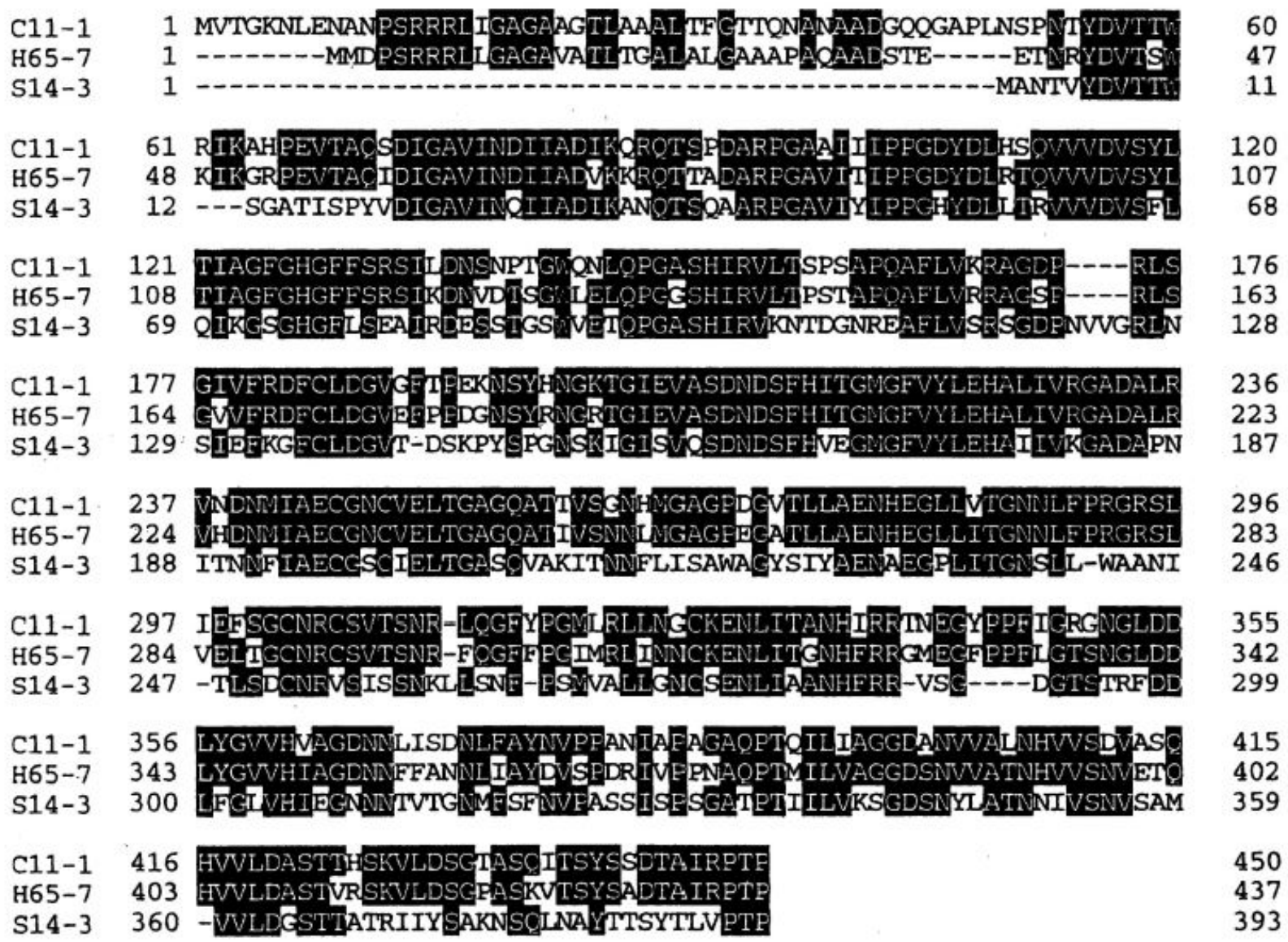

Figure 2: Alignment of the deduced amino acid sequences of inulinfructotransferases. ; C11-1, deduced amino acid sequence of inulin fructotransferase (DFA III-producing) from Arthrobater globiformis C11-1; H65-7, deduced sequence of inulin fructotransferase (DFA IIIproducing) from Arthrobacter sp. H65-7; S14-3, deduced sequence of inulin fructotransferase (DFA I-producing) from Arthrobacter globiformis $\mathrm{S} 14-3$. The identical residues are presented by white letters in black boxes.

Bo et al. reported on an enzymatic membrane reactor (EMR) for the production of oligosaccharide DFA III [13]. In this system, ultrafiltration membrane was employed and the reuse of the DFA III forming enzyme was performed. The purity of produced DFA III was improved to $95 \%$. Using this EMR system, the large scale production of the DFA III was able to achieve.

\section{Functionality of Oligosaccharide DFA III}

Suzuki et al. reported on the special functionality of the oligosaccharide DFA III using rats [14]. They performed an experiment using a rat of 5 week age and weight about $100 \mathrm{~g}$. The four groups of the rats were prepared. The groups were given a diet containing DFA III or raffinose or fructo-oligosaccharide or no oligosaccharide (control). The group of the rats given DFA III was most effective on the absorption of calcium from diet. Therefore, the combination of oligosaccharide DFA III and calcium promotes the absorption of calcium from intestines. The calcium is absorbed from a tight-junction of the intestines. The oligosaccharide DFA III has an effect on the tight-junction and promotes the assimilation of calcium. Further-more, the organic acids are formed by intestinal microorganism from DFA III. These organic acids dissolve calcium and promote the absorption of calcium from intestines.

\section{Industrialization of Oligosaccharide DFA III}

A beet sugar company in Hokkaido, Japan started a development for the industrial production of DFA III on a commercial basis around 1994. The company employed the inulin fructotransferase (DFA IIIproducing) produced by Arthrobacter sp. H65-7 [4]. As an original material, the inulin extracted from chicory was used. The inulin was imported from Germany. The sugar company produced the pure oligosaccharide DFA III powder in large scale. Using this powder, a health food maker in Japan developed a supplement containing DFA III and minerals (Fe, $\mathrm{Ca}, \mathrm{Mg}$, and so on). The sales of the supplement were started in 2004, in Japan. Now, the supplement using oligosaccharide DFA III is sold in a pharmacy and a convenience store, in Japan.

\section{Conclusion}

The oligosaccharide DFA III producing enzyme was discovered in 1973 by Uchiyama et al. [1]. This is the beginning of the basic research 
Citation: Haraguchi K (2016) Functional Oligosaccharide DFA III Forming Enzyme Produced by Microorganisms. J Exp Food Chem 2: 115. doi:

Page 4 of 4

of the enzyme. The industrial production of DFA III was started in 2004 in Japan. Therefore, it took more than 30 years from the start of the basic research to the industrial production. During this period, there were many researchers and technical specialists concerned the development for the industrial production of the oligosaccharide DFA III. Please notice that it takes a very long time for the birth of a new practical technique.

\section{References}

1. Uchiyama T, Niwa S, Tanaka K (1973) Purification and properties of Arthrobacter ureafaciens inulase II. Biochim Biopys Acta 315: 412-420.

2. Haraguchi K, Kishimoto M, Seki K, Hayashi K, Kobayashi S, et al. (1988) Purification and properties of inulin fructotransferase (depolymerizing) from Arthrobacter globiformis C11-1. Agric Biol Chem 52; 291-292.

3. Kawamura M, Takahashi S, Uchiyama T (1988) Purification and some properties of inulin fructotransferase (depolymerizing) from Arthrobacter ilicis. Agric Biol Chem 52: 3209-3210.

4. Yokota A, Enomoto K, Tomita F (1991) Purification and properties of an inulin fructotransferase (depolymerizing) from Arthrobacter sp. H65-7. J Ferment Bioeng 72: 262-265.

5. Haraguchi K, Yoshida M, Ohtsubo K (2005) Thermostable inulin fructotransferase (DFA III-producing) from Artrobacter sp. L68-1. Carbohydr Polym 59: 411-416.

6. Kang S, Kim W, Chang Y, Kim S (1998) Purification and properties of inulin fructotransferase (DFA III-producing) from Bacillus sp. snu-7. Biosci Biotech Biochem 62: 628-631.
7. Haraguchi K, Yoshida M, Ohtsubo K (2006) Inulin fructotransferase (DFA III-producing) from Leifsonia sp. T88-4. Carbohydr Polym 66: 75-80.

8. Haraguchi K (2015) Difructose dianhydride III producing inulin fructotransferase from Microbacterium sp. S48-1. Food Biotechnol 29: 156-165.

9. Sakurai H, Yokota A, Tomita F (1997) Molecular cloning of an inulin ructotransferase (depolymerizing) gene from Arthrobacter sp. H65-7 and its expression in Escherihia coli. Biosci Biotech Biochem 61: 87-92.

10. Haraguchi K, Seki K, Kishimoto M, Nagata T, Kasumi K, et al. (1995) Cloning and nucleotide sequence of the inulin fructotransferase (DFA Iproducing) gene of Arthrobacter globiformis S14-3. Biosci Biotech Biochem 59: 1809-1812.

11. Haraguchi K, Mori S, Hayashi K (2000) Cloning of inulin fructotransferase (DFA III-producing) gene from Arthrobacter globiformis C11-1. J Biosci Bioeng 89: 590-595.

12. Jahnz U, Schubert M, Baars-Hibbe H, Borlop K-D (2003) Process for producing the potential food ingredient DFA III from inulin: screening, genetic engineering, fermentation and immobilization of inulase II. Intern J Pharm 256: 199-206.

13. Bo J, Liuming Z, Tao Z, Ming M, Hua H, et al. (2010) A method produced DFA III by enzyme membrane reactor. CN Patent 201, 010, 271, 528.4.

14. Suzuki T, Hara T, Kasai T, Tomita F (1998) Effects of difructose anhydride III on calcium absorption on small and large intestine of rats. Biosci Biotech Biochem 62: 837-842. 